\title{
REGIONAL EMPLOYMENT PLANNING GRAND DESIGN: A CASE STUDY IN KARANGANYAR 1
}

\author{
Siti Aisyah Tri Rahayu \\ Faculty of Economics and Business, Sebelas Maret University, Surakarta \\ Center for Regional Policy and Institutional, Sebelas Maret University, Surakarta \\ e-mail: aisyahrahayu@yahoo.com \\ Kusnandar \\ Faculty of Agriculture, Sebelas Maret University, Surakarta \\ Center for Regional Policy and Institutional, Sebelas Maret University, Surakarta \\ Diana Tantri Cahyaningsih \\ Faculty of Law, Sebelas Maret University, Surakarta \\ Center for Regional Policy and Institutional, Sebelas Maret University, Surakarta
}

\begin{abstract}
The aims of this research are to design employment planning with a proper method, to get a prediction of supply and demand of labor, and to create a planning program in employment development in Karanganyar region to increase quality of employment and productivity as well as to raise employment welfare. It finds that Karanganyar region has an industrial and agricultural typology and that industrial sector has a greater regional gross domestic product (RGDP) than province RGDP on average. It also finds that service sector has employment elasticity greater than that of the other sectors and that the agriculture sector experiences aa decrease on employment demand.
\end{abstract}

Keywords: Population, unemployment, employment planning

JEL classificatiomumbers : J21, J22, J23

DOI:http://dx.doi.org/10.20885/ejem.vol5.iss1.art5

\begin{abstract}
Abstrak
Tujuan dari penelitian ini adalah untuk merancang perencanaan kerja dengan metode yang tepat, mendapatkan prediksi permintaan dan penawaran tenaga kerja, dan juga membuat perencanaan program pembangunan ketenagakerjaan di daerah Karanganyar untuk meningkatkan kualitas pekerjaan dan produktivitas serta meningkatkan kesejahteraan tenaga kerja. Studi ini menemukan bahwa wilayah Karanganyar memiliki tipologi industri dan pertanian, dan bahwa sektor industri memiliki produk domestik regional bruto (PDRB) yang lebih besar dari PDRB rata-rata provinsi. Studi ini juga menemukan bahwa sektor jasa memiliki elastisitas lapangan kerja lebih besar dari sektor lain dan bahwa permintaan pekerjaan di sektor sektor pertanian mengalami penurunan.
\end{abstract}

Kata kunci: Penduduk, pengangguran, perencanaan kerja

JEL classificatiomumbers : J21, J22, J23

\section{INTRODUCTION}

Employment development is closely related to economic development. There is a functional relationship between the economy with employment (Aaronson et al., 2001;

\footnotetext{
${ }^{1}$ This Paper is the result of competitive grants research funded by DIPA BLU Sebelas Maret University, 2012
}

Aaronson and Sullivan, 2002). The number of working age population has been growing for many years and has been creating unemployment. Therefore, the labor force planning must be carefully constructed in line with the development plan (Atkinson, 1982; Aaronson and Sullivan, 2002). 
The government's success in achieving the principal objectives of development in the field of labor is ultimately determined by the government's ability to influence the demand and supply sides (Moretti, 2011). In practice, the changes from both sides can be circumvented by setting policies and strategies with options targeting-development (Blundell and McCurdy, 1999; Domeij and Flodén, 2006). Labor force planning over the next 5 years, specifically, is influenced by setting a few variables, mostly economic variables (Rama, 2003).

In addition, employment issues in Indonesia are closely linked to power absorption that leads to the lack of employment giving rise to the problem of unemployment which is still quite high in Indonesia. In August 2010, the number of open unemployment in Indonesia is 7.70 million people $(6.56 \%)$ of the total population in the labor force (117.37 million). There are more than 109.67 million working population, $31.54 \%$ were part-time $\quad(<35$ day/week). Furthermore, from the 34.59 million labor are not fully working, 39.09\% are underemployed and the remaining $60.88 \%$ were part-time employment. Meanwhile, Karanganyar region population is 813,196 people, with 457,756 people are in the labor force. Mong the labor force, 427,435 have jobs while the other 30,321 are unemployed $(6.62 \%)$. This unemployment rate is bigger than that of the national unemployment rate.

Employment in Indonesia is influenced by several factors such as is foreign capital, investment climate protection, global markets, and the behavior of the bureaucracy and the wage increase. Regional autonomy in many ways also has a positive effect on employment. Poverty, income inequality, economic growth, urbanization and political stability also affect employment (Mafruhah, 2011).

This paper establishes labor force planning documents using appropriate me- thods of analysis. The method employes a systematic and comprehensive basis, as well as refers to the formulation of policies and strategies in the implementation of sustainable development programs in Karanganyar. This paper also estimates labor supply and labor requirements in Karanganyar region. In addition, this paper also facilitates the employment development which includes developing job opportunities, increasing labor utilization, improving the quality of labor, increasing labor productivity and protection, as well as increaseing labor's welfare.

This study composes regional labor force planning in a more systematic way accomodating various aspects and factors affecting employment in the Karanganyar region. It is hoped that with a good laborforce planning unemployment and poverty rates will be able to be reduced.

The Classical Theory of Adam Smith noted that the allocation of human resources effectively is a beginning in boosting economic growth. After economic growth, capital accumulation (physical) begins needed to keep the economy growing. In other words, the allocation of human resources effectively is a necessary condition for economic growth.

The Malthus Theory revealed that humans evolved much faster than agricultural production to meet human needs. Humans evolve according to geometric progression, while food production only increases arithmetically. Malthus also argued that the high number of people certainly lead to lower production level and the only way to overcome the problem is by controlling the population growth. Some ways out offered by Malthus is to delay the age of marriage and reduce the number of children.

The Keynesian Theory argued that in fact, the labor market does not work as expected by the classical view. Sometimes, workers have labor union which will reduce the wage to decrase. The decrease in wage 
rate will be followed consequtively by lower income, lower purchasing power, and eventually by lower consumption. Lower purchasing power will also reduce common prices which will further be followed by lower marginal productivity of labor, and eventually lower the demand for labor. If the price reduction is not so large, the productivity curve will fall only slightly. Despite the growing number of labor still less than the amount of labor supplied. Even worse if prices fall dramatically, this causes the value of the marginal productivity of labor curve down drastically, and the number of labor becomes smaller and unemployment is becoming increasingly widespread.

The growth theory of HarrodDomar stated that investment not only creates demand, but also increase production capacity. Bigger production capacity requires greater demand to absorb it; otherwise, the production will decrease.

One common problem in work force is the unbalanced labor demand and supply, in which labor supply is greater than the labor demand which creates excess supply of labor (Malykhina, 2005).

Labor wage affects production costs The increase in the wage rate will lead to higher production costs, thereby increasing the price of product. This will reduce the demand of the products, and eventually reduce the labor demand, known as production scale effect or scale effect. Assuming the price of capital goods is fixed, a wage increase will be followed by the replacement of labor by machines (capital), known as the substitution effect (Sayre, 2001).

The use of technology determines the required labor in the production process. It is the engine's ability to produce output in quantities far greater than human ability that will reduce the demand for labor (Ohanian et al., 2006).

Labor supply is the amount of labor that can be supplied by labor in every possible wages within a certain period (Mulligan,
2002). In the classical theory of human resources, labor are individuals free to decide whether to work or not. They even free to set the number of hours they want. This theory is based on the theory of the consumer, in which individuals aim to maximize the satisfaction subject to the constraints (Meghir, 2011). Individual satisfaction can be obtained through the consumption or enjoy leisure time. The constraints faced by the individual is the level of income and time.

The combination of non-market time and market goods is the best combination that lies on the highest indifference curve that can be achieved with certain constraints. At a certain wage level, individual working time will increase if the wage increases. Added wage actually reduces the time provided by an individual to work. It is called backward bending supply curve (Mrohorolu, 2009).

Individual's decision to increase or decrease the working time is influenced by the level of wages and non-labor income. The level of productivity is always varying according to the phases of the production of the pattern initially rose to a peak and then decline. The greater the elasticity the greater role of labor input to produce output, meaning the smaller the amount of labor demanded (Clouse, 2006). To describe the pattern of a combination of factors of production that are not comparable (variable proportions), a commonly used tool is the isoquant curve. It is a curve that describes various combinations of factors of production (labor and capital) resulting in the same quantity of output. The slopes of isoquants describe marginal rate of technical substitution (MRTS). It is intended to look at the relationship between the factors of labor and capital which is the slope of the isoquant curve (Rogerson, 2007).

The high population growth in Indonesia creates problems of unemployment, poverty, and migration. Combined with the low quality of the labor force, it creates unemployment. In addition, the 
high unemployment level in Indonesia is also caused by the fact that industrial sector is not big enough to absorb the labor force (Ngai and Pissarides, 2004). Unemployment has become the main problem in Indonesia.

Labor requirement is the number of jobs available in an economy that is expressed in the number of units of people working on each or all sectors to carry out production activities. The main factors in projecting the need for labor is the target of national/regional and sectoral economic growth. Based on the economic growth target then we find the relationship between employment growth with economic growth (Lee and Wolpin, 2004)

Forecast is done through three basic stages. The first stage is forecasting total Gross Domestic Product (GDP) based on a number of macroeconomic parameters assumptions, which mainly comes from the total GDP of Indonesia, and using econometric models. The second stage is forecasting value-added of the main business field, namely agriculture and the services performed, while the manufacturing industry is considered as the residual of GDP. We use an econometric model to forecasts, assuming the value added of each business field group is a function of the previous value. The last stage is predicting job opportunities based on the value-added business field, obtained from stage two.

The problem is that the current employment climate has not been able to encourage the employment opportunities. The government's efforts in improving the regulation of Law No. 13 of 2003 concerning employment can not be implemented properly. Furthermore, the equilibrium between the need for investment in long term/medium meet the needs of jobs for unemployed people who want a good job, including strive for permanent labor acquire consistent with applicable regulations.

Labor demand is essentially dependent on the output of the company/industry (micro level); the higher the output, the higher the labor demand. Well known as the derived labor demand. At the macro level, national output (GDP) determines the rate of employment in an economy; a country's economic growth creates new employment opportunities. In this regard it is important to analyze how the sensitivity of the output changes to the employment growth rate. We use Employment Elasticity (Ekk) which is the ratio of output growth with employment growth.

Ekk sector could be calculated based on field work/business in an economy. In Indonesia, for example, there are 9 sectors/activities from agriculture to services, or can be grouped into 3 major groups such as agriculture, manufacture and services (AMS: Agriculture, Manufactory and Service), the summation/combination of these will be the Total Ekk. The Ekk can also be used as a starting point for projecting employment through several scenarios in planning for both macro and micro policies.

\section{METHODS}

The scope of the grand design of employment planning area is the employment in the Karanganyar region. In accordance with Indonesian Industrial Classification (KLUI) which refers to the International Standard of Industry Classification (ISIC), an economy is divided into 9 sectors of the field of business, namely: (1) Agriculture, (2) Mining, (3) Manufacturing, (4) Electricity, Gas and Water, (5) Building, (6) trade, (7) Transport and Communication, (8) Financial and (9) Services. However, for reasons of data availability, the nine sectors are classified into 3 major sectors, namely (1) Agriculture consists of the agricultural sector alone, (2) Manufacture sector consists of Mining, Manufacturing, Electricity, Gas and Water, and Building and (3) Services sector consists of Trade, Transport and Communication, Finance, and other services. 
Data used include social issues, general economic and employment data in Karanganyar region that includes GDP, the level of economic activity, the number and population growth, births, deaths and migration, the number and employment growth, labor supply, unemployment, underemployment, labor force participation rate, dependency ratio of the population and laborforce education.

The data sources used in the preparation of the Grand Design Employment Planning comes from Sakernas, Susenas, population census conducted by BPS, and institution related to this research (SKPD).

Various tools of analysis used in the preparation of Grand Design PTKD Karanganyar region. The first is a descriptive analysis to describe the general situation of the economy and employment in the Karanganyar region. The second tool is theQuotients area, to determine whether Karanganyar region typology is of agriculture, manufacture, services or mixed.

In determining the typology of Karanganyar, the steps are as follows. Calculating ratio of RGDP province/RGDPr egion and the proportion of employment in GDP/GDP E mployment is calculated based on both national and Karanganyar region by the business sector that divide into Agriculture (A), Manufacture (M) include mining, manufacturing, electricity, gas and water and construction and Service (S) sector comprising trade, hotels, restaurants, transport and communications, finance, leasing and business services and other services.

We have several steps to determine the coordinates in each typology. At the first step, we draw a straight line between the proportion of GDP and employment of each sector of the provincial economy, where the line was later used as a boundary grouping of quadrant I, II, III and IV, as in Figure 1.

Quadrant I shows that the proportion of GDP contribution and the employ- ment is greater than that of the proportion of provincial.

Quadrant II shows that the proportion of GDP contribution is smaller that of the proportion of provincial while the employment proportion is greater than that of the proportion of provincial.

Quadrant III shows that the proportion of GDP contribution and the employment is smaller than that of the proportion of provincial.

Quadrant IV shows that the proportion of GDP contribution is greater that that that of the proportion of provicial while the employment is smaller than that of the proportion of provincial.

The next step is the employment elasticity analysis. To conduct the analysis, we must calculate the growth rate RGDP sectoral and total economic activity. Then, we calculate the rate of employment by sector of economic activity, and calculating employment elasticity coefficient (Ekk) in each sector in economic activity using the following formula:

$E k k=R K K / R G D P$

Simple-E Analysis is used to determine the requirements and employment projections. Labor requirements are the number of jobs available in an economic system that is expressed in the number of units of people working on each sector to carry out production activities. The main factors to be considered in projecting the need for labor is targeting economic growth of national/regional and sectoral economic growth.

Based on the economic growth target then, the paper search for patterns of relationship between the growth of employment opportunities and economic growth using a model of a particular technique. The paper uses econometric models, accommodating both simultaneous and lag factors, to conduct the forecast. 


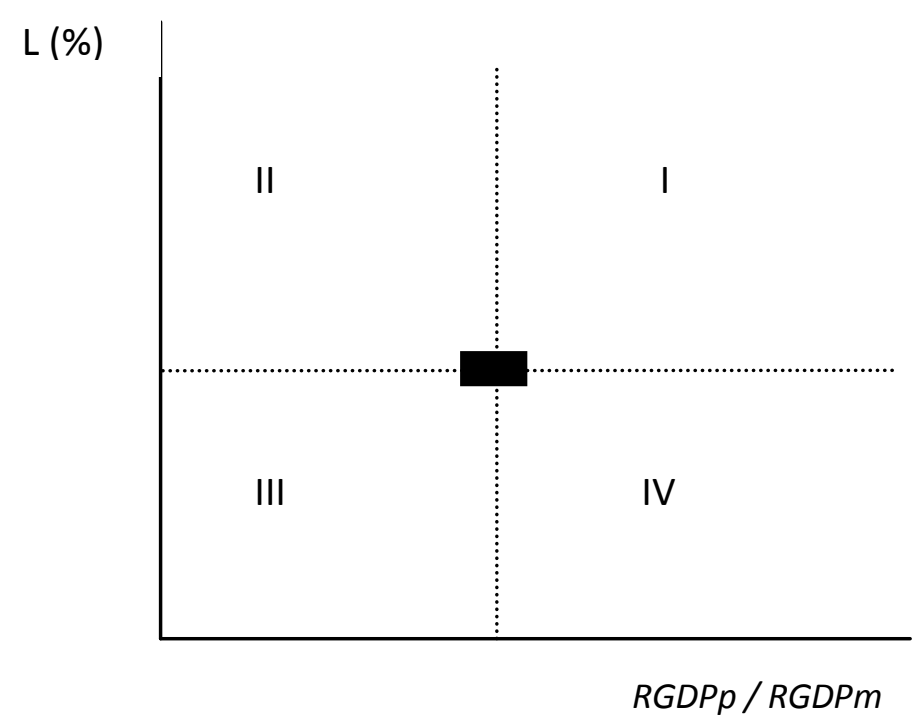

Figure 1: Employment Quadrant

The method to estimate is the Simple-E, which has slight advantages compared with regular OLS models as Simple$\mathrm{E}$ is a model that simultaneously and insert lag, so it can be used more accurately to predict at least the next five years. The weakness of Simple-E is that it needs longer time series data, at least 8 years span.

The modeling operation is performed in two stages. First, predict the overall GDP by a number of macroeconomic assumptions. Second, based on GDP forecasts that predicted outcome value for each field group effort. The estimated unemployment rate is calculated simply as the difference between projections of the labor force and employment forecasts for the same year.

The formulation of the model uses two main blocks: blocks of labor economics, where each is broken down into three main groups of economic activities: agriculture, manufacturing and services. The formula of the models are expressed in some of the following equations:

Economic block.

NTB-Services:

$N T B a, t=f(N T B a, t-1)$

Manufacturing
NTBs, $t=f(N T B s, t-1)$

Agriculture (residual)

$N T B m, t=P D R B t-N T B a, t-N T B s, t$

(The model used is placed as residual agricultural NTB, this is because the Karanganyar region is an industry typology in 2007 as well as services in 2009).

Labor force block

Labor-field farming

$L a, t=f(N T B a, t, L a, t-1)$

Field-labor manufacturing business

$L m, t=f(N T B m, t, L m, t-1)$

Field of labor-service business

$L s, t=f(N T B s, t, L s, t-1)$

Total labor force

$L t=L a, L m+t, t+L s, t$

The model is used for all typologies regions/cities, the typology of agriculture, manufacturing, services and agriculture combined, manufacturing and services). In practice, the modeling process takes place over and over until a model was considered the most appropriate (the best fitting model). 


\section{RESULTS}

\section{Employment Elasticities}

The amount of labor in the region indicates that while Karanganyar is an agricultural area, but the majority of the laborforce is in the industrial sector, shown in the following table:

Table 1: Employment Elasticity (EKK) Sector in Karanganyar, 2009

\begin{tabular}{lr}
\hline Sectors & $R k k / R G D P$ \\
\hline 1. Agriculture & -0.12 \\
2. Mining & 2.87 \\
3. Manufacture & 0.11 \\
4. Electricity, Gas \& Water & 22.03 \\
5. Building & 0.50 \\
6. Trade, Hotels \& Restaurant & 6.30 \\
7. Transportation \& Comunica- & \\
$\quad$ tion & 6.27 \\
8. Finance, Leasing \& Bussi- & \\
$\quad$ ness Services & 6.37 \\
9. Other Services & 0.00 \\
Total & 0.07 \\
& \\
Agriculture & -0.12 \\
Manufacture & 0.37 \\
Services & 0.77 \\
Total & 0.07 \\
\hline - Agriculture (sector 1) & \\
- Manufacture (sector 2, 3,4 \& 5) & \\
- Service (sector 6, 7.8 and 9) & \\
Source: Sakernas, BPS (2010) &
\end{tabular}

\section{Karanganyar Typology}

In determining the typology of a county/city, an analysis is conducted based on the performance of the economy and employment. In this analysis, the proportion of Regional GDP is compared with the proportion of GDP and employment in the province in each economic sector. The results of the calculation of the proportion of Regional GDP/ provincial GDP using BPS and Susenas is as follows.

Once the coordinates as a basis for determining the typology of Karanganyar region is known, then the next step is to make a point in each typology in proportion to GDP and employment in each economic sector. Referring to the average proportion of RGDP region/provincial RGDP and employment provincial/region during the period 2000-2010, it appears that the position of the farm typology Karanganyar is in quadrant IV which shows the proportion of GDP Karanganyar is larger than the GDP of Central Java Province. Meanwhile, employment in the agricultural sector of Karanganyar region is smaller than the absorption of labor in the agricultural sector in Central Java Province.

\section{The Typology of Manufacture Sector in Karanganyar}

The coordinates indicates the proportion Regional GDP/provincial GDP and labor absorption. It appears that the position of the Region is in quadrant I. Karanganyar quadrant I shows that the proportion of GDP Karanganyar GDP larger than Central Java. Similarly, the employment in manufacture sector in Karanganyar larger than employment in manufacture sector in Central Java Province.

\section{The Typology of Services Sector in Karanganyar}

It appears that the position of the Region is in quadrant III Karanganyar. Quadrant III shows that the proportion of GDP Karanganyar is smaller than the GDP of Central Java Province. Likewise, service sector employment in Karanganyar is smaller than the service sector employment in the province of Central Java.

Based on the above analysis, it can be seen that in Quadrant I, the proportion of sector contribution of GDP in Karanganyar is greater than provincial GDP - and that the employment sector in the region is larger than employment sector in the province is the industry sector. Thus, based on data in the year 2000-2010, Karanganyar Region's Typology is manufacture. 


\section{Estimated Result of Labor Supply in Karanganyar}

Table 2: The Proportion of GDP and Labor Absorbtion in Central Java Province and Karanganyar, 2009

\begin{tabular}{ccccccc}
\hline \multirow{2}{*}{ Area } & \multicolumn{9}{c}{ Setors } \\
\cline { 2 - 7 } & $R G D P$ & $L$ & $R G D P$ & $L$ & $R G D P$ & $L$ \\
\cline { 2 - 7 } & 23,50 & 27,83 & 49,23 & 50,30 & 27,28 & 21,87 \\
Karanganyar & 23,94 & 35,53 & 40,91 & 25,29 & 39,15 & 39,18 \\
Province & 19,94 &
\end{tabular}

Source: Karanganyar Dalam Angka, BPS (2010)

Projections of labor force needs to determine how much inventory to meet the laborforce needs in the sectors of the economy. The population data are obtained from the Census of Population (SP) 2000 and Census of Population (SP) 2010, while the value are obtained from the LFPR National Socioeconomic Survey (SUSENAS) from 2006 to 2009.

Labor supply in 2011 - 2015 is done by extrapolation models (geometrical method), using the following formula:

$P t=P o .(1+r)^{t}$

where $P t$ is total population/labor force in year $t, P o$ is total population/labor force base year, $r$ is annual growth rate, assumed constant, and distance $t$ is time (years) from year 0 to year $\mathrm{t}$.

The calculation formula is the assumption that growth in the same period of growth in 2000-2010, which includes: Population growth $=1.083$ percent per annum; Employment growth $(15$ years and above $)=-$ 0.01 percent per year; Employment growth $(15-64$ years $)=-0.02$ percent per year; Employment growth $=0.99$ percent per year.

Based on these assumptions, the total population in 2011 was estimated at 891,828 persons where 663,447 persons or 74.39 percent were labor force (population 15 years and over). The number of labor aged 25-59 years (adult labor) have a proportion of 43.82 percent of the population, labor force aged 15-24 years (young labor) amounted to 18.33 per cent and labor aged 60 years and over (age labor force) equal to 12.24 percent. Total laborforce is 663,447 people, as many as 426,937 or about 64.35 percent is projected to enter the labor market.
At the end of the projection (2015), the population is estimated at 931.095 people, where 692,657 people or 74.39 percent of which is labor (population aged 15 years and over). If seen from the composition of the laborforce is also the largest proportion held by the group 25-59 years by 408,401 people, a young group of 170,650 people and the elderly amounted to 113,965 souls. Of the total number of labor is expected to enter the labor market of 445,754 people will enter the labor market.

\section{Estimated Result on Demand of Labor Simple-E Model}

\section{Calculation of GDP}

We used the Simple-E Data from 1999 to 2009 and obtained the following results:

$$
Y T=\begin{aligned}
& -85.017+6,207.2 L N(L A G 1 . P D B) \\
& (-13.3) \quad(13.9)
\end{aligned}
$$

LS: R.960; AR.956; DW.77; F194.2; DF8 (p5\% R.36/F4.46/t2.31); RSS347209

From the above equation, the constant is - 85017 , and the coefficient of independent variable is 6207.2. The coefficient of determination is 0.96 , meaning that $96 \%$ of the variation or change in GDP Karanganyar region indicated by GDP in the previous year. F-test and $t$ test are significant statistically, which means GDP is significantly influenced by GDP the previous year.

After the simulation results obtained for the prediction of GDP in 2011 was Rp 5945.998 billion. While the results of calculations performed preliminary figures BPS in 2011 was Rp 5452.4355. GDP forecast for 2011 to 2015 respectively - 
were as follows: $\mathrm{Rp} 5945.998$ billion in 2011, Rp 6191.371 billion in 2012, Rp 6427.412 billion in 2013, Rp 6654.805 billion in 2014, $\mathrm{Rp} 6874.161$ billion in 2015, and Rp 7086.030 billion in 2016.

NTB estimated manufactureg roup

$$
\begin{gathered}
Y M=-773.59+213.37 L N(L A G 4 . Y M) \\
(-1.57) \quad(1.91) \\
-1.6729 Y S+0.77813 Y T \\
(-8.67) \quad(17.6) \\
+0.04396 L A G 3 . Y S \\
(0.402)
\end{gathered}
$$

LS: R.999; AR.998; DW1.53; F775.9; DF2 (p5\% R.97/F19.3/t4.3); RSS726.434

The results of the above equation shows that the industrial sector is a function of NTB four years earlier industrial sector and the service sector in this year, GDP this year and the previous three years the service sector. Coefficient of determination showed the $99.9 \%$, which means $99.9 \%$ of the variation or change in the NTB can be explained by the industrial sector four years ago, the service sector of this year, GDP this year and the previous three years the service sector. The $F$-test shows that each of these variables together have the same effect on $Y$ for manufacturing.

From the estimated equation, the predicted $Y$ for the manufacturing sector in

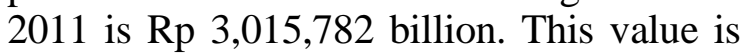
similar to the that of the BPS calculation for GDP in 2011, while the figure for the manufacturing sector of $\mathrm{Rp} 3.015 .7816$ billion. That is on the temporary differences are not so great. Based on this equation, the simulated and generate predictions NTB for the manufacturing sector are as follows: $\mathrm{Rp}$ 3383.878 billion in $2011, \mathrm{Rp} 3564.17$ billion in 2012, Rp 3717.829 billion in 2013, Rp 3860.107 billion in 2014 , Rp 4010.146 billion in 2015, and $\mathrm{Rp} 4143.158$ billion in 2016.

Estimated NTB services business group

$Y S=380.48+0.2721 Y T+0.1629$ LAG1.YS
(1.51) (0.627) (0.943)

- 0.070255 LAG1.YT

$(-, 433)$

\section{LS: R.753; AR.629; DW1.73}

The results of the above equation shows that the NTB services of this year is a function of NTB services one year earlier, GDP this year and the previous year. Coefficient of determination equal to $0.629 \%$ indicates that $62.9 \%$ of the variation in $Y S$ affected by the previous year, this year and $Y T$ previous year.

From these equations, it can be predicted that in 2011 the NTB for service business is Rp 1289,564 billion. This value is very close to the results of preliminary calculations conducted by BPS for service business is Rp 1289.5639 billion. The difference did not reach 200 million of the previous data show that this model can be used to predict the service sector in the Karanganyar. After the simulation model, it can be obtained the prediction of NTB services business from 2011 to 2016 as follows: Rp 1317.224 billion in 2011, Rp 1330.059 billion in 2012, $\mathrm{Rp}$ 1354.778 billion in 2013, Rp 1381.975 billion in 2014, Rp 1409.146 billion in 2015, and $\mathrm{Rp} 1435.653$ billion in 2016.

\section{NTBE stimates for Agricultural Field}

Farming is located in quadrant IV because neither employment nor RGDP is below average, nationally. We used this identity, then the following equation is obtained:

$Y E S=Y T+(-1 Y M)+(-1 Y S)$

NTB Agriculture obtained from total GDP is reduced by NTB manufacturing and services. The results of the calculations using the equations obtained the value for the year 2011 amounted to USD 1147.09 billion. When compared to the value of GDP based on preliminary calculations by the BPS of Rp 1147.0901 billion, was relatively close to its value. This shows that the above equation can reasonably be used to make predictions. After simulation $Y A$ values obtained in 2011 up to the year 2016 are as follows: $\mathrm{Rp} 1244.896$ billion in 
2011, Rp 1297.142 billion in 2012, Rp 1354.805 billion in 2013, Rp 1412.722 billion in 2014, $\mathrm{Rp} 1454.537$ billion in 2015, and Rp 1507.220 billion in 2016.

\section{Estimated Demand for Labor}

Estimating the labor requirements is very important to see how much absorption of the labor force in the Karanganyar region. Based on the calculation of the Simple-E, the results of each sectors/activities are as follows:

\section{Estimated Labor for IndustryS ectors}

Modeling results:

$$
\begin{aligned}
L M= & 189202-0.49422 L A G 2 . L M \\
& (1.82) \quad(-1.13) \\
& -31.013 Y M+36.945 Y T \\
& (-0.305) \quad(0.486)
\end{aligned}
$$

LS: R.282; AR <.001; DW2.72; F.7; DF5 (p5\% R.76/F5.19/t2.57); RSS4760285000

From the results, it is obtained that labor requirements are affected by the manufacture sector, manufacture sector two years earlier, NTB manufacture sector this year and also this year's total NTB. After the model simulation was obtained that the labor requirements for the industrial sector has declined. This can be caused by many things, among others as more modern technology that industrial companies and factories prefer to use a machine with high technology and reduce the labor-intensive, so the need for decrease more labor.

\section{Estimated Employment Needs in Services Sector}

Modeling results:

$$
\begin{aligned}
L S= & 222,240-0.080656 L A G 3 . L S \\
& (0.831) \quad(-0.118) \\
& -155.18 L A G 1 . Y S \\
& (-0.67)
\end{aligned}
$$

$$
\begin{aligned}
& +31.011 L A G 2 . Y T-66.938 Y S \\
& \begin{array}{l}
(1.08) \quad(-0.259)
\end{array}
\end{aligned}
$$

LS: R.284; AR <.001; DW3.12; F.3; DF3 (p5\% R.92/F9.01/t3.18); RSS5663651000

The above model shows that service sector employment is determined by the number of service sector employment needs three years earlier, the service sector NTB NTB previous year and a total of two years earlier, and NTB service sector for this year. From the results of these calculations, labor requirements of the service sector from year to year has increased significantly. Even being the biggest contributor of labor requirements in total. This is in line with the typology Sukoharjo region that tends to be typology services.

Estimated Labor Requirements of Agricultural Sector

Modeling results:

$$
\begin{aligned}
L A= & 334,516-0.31914 L A G 3 . L A \\
& (1.46) \quad(-0.568) \\
& -157.49 \text { YES }+0.0040091 \quad L A G 1 . L A \\
& (-1.52) \quad(0.00722) \\
& -14532 \text { DUM.2009 } \\
& (-0.593)
\end{aligned}
$$

LS: R.702; AR.305; DW1.97

The above model suggests that the labor needs of the agricultural sector is influenced by the needs of the agricultural sector labor force three years earlier, NTB The agricultural sector this year, and labor requirements prior year. From the estimation results using the model, found that the agricultural sector had declined, but then increased even though the percentage increase is not big.

The estimation results using simple models can be demonstrated as follows:

Table 3: Estimated Labor Needs in the Karanganyar Region, 2012 to 2015

\begin{tabular}{lccccc}
\hline \multicolumn{1}{c}{ Sectors } & 2011 & 2012 & 2013 & 2014 & 2015 \\
\hline Agriculture & 97569.66 & 91689.66 & 83545.33 & 81217.31 & 76498.85 \\
Manufacture & 201155.4 & 201142.5 & 211944.3 & 215939.1 & 214041.2 \\
Services & 84606.96 & 90789.35 & 102000.7 & 104668 & 105449.8 \\
\hline Total & 383332 & 383621.5 & 397490.3 & 401824.5 & 395989.9 \\
\hline
\end{tabular}




\section{CONCLUSION}

The typology of Karanganyar in 2010 is a manufacture and agriculture economy. The industral sector has greater proportion in GDP and th employment is higher than the average of provincial or in quadrant II. The elasticity of employment opportunities in the agricultural sector in the Karanganyar Region apparently has a negative value. This means that an increase in the rate of absorption rate of growth of the economy led to declining job opportunities in the agricultural sector. Meanwhile, the employment elasticity calculations for the period 2002-2010 in the industrial and service sectors have a positive number. This means that an increase in the rate of economic growth is boosted employment growth in both sectors. Service sector employment elasticity is higher than the other two major sectors in the Karanganyar Region.

The Simple-E model obtained there is a very large reduction in the need for labor in the agricultural sector which is likely caused by a shift in the economic structure of the industry and services. The service sector and agriculture can still be used as an employment absorption that should be developed and handled professionally by the Karanganyar region.

Policy strategies that can be collaborated between the mission of the Department of labor and 52 priority programs Karanganyar region are as follows. Improving the quality of human resources and professional is by completion of basic education and improving the quality of secondary education. Specifically the increase of the quality of vocational schools are meant to be able to bridge the skilled labor requirements and ready to work and be able to use the machine.

Expanding the employment opportunities and job placement by attracting investors both within and outside the country to open a business in the region so that it can accommodate Karanganyar local resources. In order to realize this then the priority program of work that can be drawn from the government's 52 priority work program are the creation of a favorable climate of investment, increased infrastructure investment support, and simplification of business regulation. This will be useful in opening up the area to invest and create new jobs in the fields of manufacture, services and agriculture.

Increasing the growth of new entrepreneurs and existing SMEs development with work program priorities: simplification of business regulation, increased risk financing schemes, environmental improvements clusters, and development of the economic value of creative activity. The development of the creative economy cluster system is expected to improve the competitiveness of SMEs especially followed by an increase of financing schemes both nationally and locally. Simplification of business regulation is also useful to encourage SMEs improve their legality.

Increased productivity and quality of agricultural products that are not only about food security but it also opens up new employment opportunities for the agro-industry and agribusiness. In this context, agriculture products are not sold as a feedstock/raw material but as processed materials that have a high added value and employment opportunities and business opportunities for the community.

In order to support policy strategies that have been implemented in the year plan, it needs some support activities that must be developed and implemented including the improving employment management information system. Information is the most important in the development of the potential of the community, including in terms of manpower. With Solid and applicable policy there will be symmetrical information between the community and the government employment service.

Expansion program and employment opportunities through employment among provinces/regions and between countries through intense socialization with the community Increased laborforce skills through training with the BLK and BPSDM at the region, provincial or even national scale.

Labor protection programs such as the development of industrial relations are forged and always controlled so as not to cause endless problems relating to rights and obligations of SME labor. 


\section{REFERENCES}

Aaronson, D. and D. Sullivan (2002), "Growth in Worker Quality," Chicago Fed Letter, Federal Reserve Bank of Chicago, February.

Aaronson, D., K.H. Park and D. Sullivan (2001), “Growth in Worker Quality” Economic Perspectives, Federal Reserve Bank of Chicago, 4, 53-74.

Aaronson, S., B. Fallick, A. Figura, J. Pingle and W. Wascher (2006), "The Recent Decline in the Labor Force Participation Rate and Its Implications for Potential Labor Supply," Brookings Papers on Economic Activity, 1, 69-134.

Atkinson, A.B. (1982), "Unemployment, Wages, and Government Policy," Economics Journal, 92, 45-50.

Blundell, R. and T. McCurdy (1999), "Labour Supply: A Review of Alternative Approaches," The Institute for Fiscal Studies, Working Paper Series No. W98/18, in Handbook of Labor Economics, Volume 3, Elevier Science B.V .

Clouse, T. (2006), "Firms in China Faced with Tight Supply of Skilled Labor," Workforce Management, 11(85), 37 - 38.

Domeij, D. and M. Flodén (2006), "The Labor-Supply Elasticity and Borrowing Constraints: Why Estimates are Biased," Review of Economic Dynamics, 9(2), 242-262.

Lee, D. and K. Wolpin (2004), "Intersectoral Labor Mobility and the Growth of the Service Sector," Econometrica, 74(1), 1 - 46

Mafruhah, I. (2011), "Preparation of the Regional Employment Projections Sukoharjo years 2011 to 2015," Research Paper, Co-operation with the Department of Labor Sukoharjo.

Malykhina, E. (2005), “Supplying Labort o Meet Demand," Information Week, March 21.

Meghir, C. and L. Pistaferri (2011), "Earnings, Consumption and Life Cycle Choices," in Card, D. and O. Ashenfelter (eds), Handbook of Labor Economics, Volume 4b, $1^{\text {st }}$ Edition 2011, Elsevier B..VNorth Holland Publications.

Moretti, E. (2011), "Local Labor Markets" in Card, D. and O. Ashenfelter (eds), Handbook of Labor Economics, Volume 4b, $1^{\text {st }}$ Edition 2011, Elsevier B.V., North Holland Publications.

Mrohorolu, S. and S. Kitao (2009), "Labor Supply Elasticity And Social Security Reform," Working Paper, Center for Retirement Research, Boston College.

Mulligan, C.B. (2002), “A Century Of Labor-Leisure Distortions,” Working Paper, 8774, February.

Ngai, R. and C. Pissarides (2004), "Structural Change in a Multi-Sector Model of Growth," Unpublihsed Paper, London School of Economics.

Ohanian, L., A. Raffo, and R. Rogerson (2006), "Long-Term Changes in Labor Supply and Taxes: Evidence from OECD Countries, 1956-2004," Working Paper 12786, National Bureau of Economic Research, Inc.

Rama, M. (2003), “Globalization and Workers in Developing Countries,” World Bank Policy Research Working Paper 2958, January.

Rogerson, R. (2007), "Structural Transformation and the Deterioration of European Labor Market Outcomes," Working Paper 12889, National Bureau of Economic Research, Inc.

Sayre, E.A. (2001), "Labor Demand and the Wage Gap in the West Bank and Gaza Strip," Contemporary Economic Policy, 19(2), 213 - 224. 